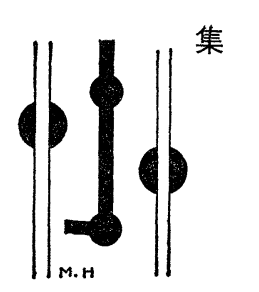

1. は じめ に

近年に拉ける機械構造物の発達は著しいものがあり, その使用条件も年々苛酷の度を加えている。これらの機 械構造物の中で特に高温, 高応力のもとで用いられる部 材でクリープが問題になるような場合，その材料の開発 扣よび使用するに際しての設計基淮については多大の関 心が払われて抒り, これらの方面関する研究には工業 界からも多くの要請がなされている.

高温, 高応力のもとでの金属材料のクリープ挙動に関 しては古くから微視的，ないしは原子論的な立場に立脚 して，金属材料の高温クリープに拈ける本質的な機構を 解明せんとする金属物理学的な分野加ら，より巨視的， 力学的な立場に立脚してその材料の実際工業面での使用 に際しての設計基準を提供することを目的として, 複難 な条件下での力学的なクリープ挙動を解明せんとする材 料試験の分野に到るまで多方面にわたつて研究が行なわ れてきて扣り，これらに関する数多くの研究成果が報告 されている(1).

金属物理学的な観点に立脚した研究は1950年代の Wood (2), McLean(3) Бによる飛躍的な研究の進歩以来, 現在に到るまで数多くの研究者によつて実験, 観察が進 められて抒り(3), とくに最近の電子顕微鏡による直接観 察や高分解能 X線回折装置の発達はクリープ変形中に金 属材料内部に生じる結晶微細構造の変化に関してわれわ れに多くの知識を提供し，これらを基䂵にしたクリープ 変形に関する転位論的な解釈る大きく進歩している(3). しかしながら, これらの実験研究の多くは, その理論的 根拠の精確さを求めんがために, 実験条件も非常に単純 なものが多く、たと充ば実験に使用される素材にしても， 純金属衿よびその合金の単結晶または粗大結晶粒試料で ある場合が多く，またそのクリープ条件も一定温度のも とに打ける一軸引張り荷重による静クリープ試験など,

* 京都大学教授; 工学部機械工学教室

** 京都大学工学部

(1) たとえば A.H.Sully: Recent Advances in Knowledge Concerning the Process of Creep in Metals, Progress in Metal Physics, 6(1959), 135.

(2) W.A.Wood and W.A.Rachinger: J.Inst.Metals, $76(1949 \sim 50), 237$.

(3) D.McLean and M.H.Farmer: J.Inst.Metals, 85 (1956 57) , 41 .
平修二* 中西英 介**

非常に単純化されている場合が多い, しかしながら，こ れらの研究結果は金属の高温に和ける変形挙動に関して われわれに多くの知織を与え，工業用高温材料の開発打 よび高温に特いて使用される機械構造物の設計基準に関 して多大の貢献をなしていることは言を待たないのであ るが，未だこれら基楚的な分野での研究結果が直ちに工 業分野での応用に結びつけられる場合はむしろ少なく， 基礎的な分野での研究と工学的な応用面との間には大き なギャップが存在していることを認めざるを得ない。

一方, 巨視的, 力学的な観点に立脚した材料試験の立 場に括いては，実際の機戌造物の構成材料となる実用金 属材料を用い, 複雑な条件下でのクリープの力学的な挙 動を追求し，それらの実験から得られた成果を，直ちに 実用機械構造物の設計基準に対する知識として利用せん とするものである。したがつて，これらの研究に用いら れる素材は多くの不純物を含み, 複雑な組成を有するも のが多く, その試験条件も変動温度下のクリープ, 変動 応力下のクリープ,動クリープ,多軸応力下のクリープな ぞ, 複難なものが多い(4). これらの研究は前述の如く, 出来るだけ実際の使用条件に近い条件のもとで行なわれ た材料試験の結果から，直らに実際の機械構造物の設計 に際してのデータを得ることを目的としたものである以 上，工業方面への大きな貢献をなしていることはいうま でもないのであるが，材料の相違やわずかの使用条件の 変化に対しても, その都度実験する必要があり,また, これらの試験によつて得られた設計基準に対してはその 物理的根拠がそしく，このような複雑な条件下でのクリ 一プを統一的，体系的に把握するには济ど遠い現状にも る. とくに本論文で取り扱らクリープ現象のごとく, 高 活性過程に抢ける変形問題に関しては材料試験によるだ けでは問題の本質的な解決が見出し得ないことは明らか であろ

以上述べたごとく，クリープ変形に関する研究は原子 論的な立場に立脚する金属物理学の分野から巨視的な材 料試験の立場に到るまで種々の段階での研究態度が存在 するわけであるが，これら両極端での研究分野の間には 未だ大きなギャップが存在している.

(4) たとえば ASTM STP, No.165, Symposium of Effect of Cyclic Heating and Stressing on Metals at elevated Temperature, (1954). 
このような観点に立脚して，筆者らは以前よりこの両 分野での研究成果を統一的に解釈し, 両分野の境界領塔 に特いて新しい材料工学の分野を設立することが急務で あることを提唱して来た。すなわち，物理学の分野です でに確立された物理学的な実験手段, 理論などを駆使し て実際工業面に特いて生ずる種々の問題点を物理的根拠 のある方法で把握して，はじめてその材料を使用するに 際しての真の意味で設計強度を論ずることになるである う。近年材料工学の分野に蛙ける発展の方向を見渡した とき，その進歩は遅々としたものであるが一歩一歩との 方向へ近づきつつあることを著者らは確信している．本 論文に打仠る応力変動下のクリープに関する研究の過程 をらり返つて見るとき，この分野に扣ける研究の発展の 方向も自ら上述の分野に向つて進歩をかさねていること が明らかとなるであろう。

以下, 応力変動下のクリープの諸問題に関して諸外国 の研究成果括よび筆者らの乏しい経験について述べる が，この小文から変動応力下のクリープに拈ける諸問題 に関する知識のみならず, 広く材料工学の発展の過程沶 よび将来に関して, 筆者らの思想の一端を把握して戴け ればこれに優る幸はない。

\section{2. 変動応力下のクリープ}

\section{(1) 緒 言}

機械構造物の設計強度を論ずる場合，常温においてb かなり多くの事項について注意する必要があるが，高温 に打いてはその使用条件がさらに複雑となる。一般に高 温に怙ける変形に際してはその過程が活性化過程である ために加工硬化, 回復(組織回復とひずみ回復), 析出, 変態扔よびそれらの相互作用がその材料の力学的挙動に 大きく影響を与える。

さらに, 高温, 高応力のもとで用いられる部材でクリ ープが問題になるような場合, 温度や応力が使用期間中 一定であるということはまず考学られない。たとえばガ スタービン, 蒸気タービン, ボイラーに打けるごとく, 負荷の変動に応じて部材の温度拉よび応力が大きく変動 する場合がある(5)。このような場合，その機械部材の変 形および破壊の挙動は単純な静クリープの場合より,よ り複雑となる。

通常,このような複雑な条件下でのクリープ挙動に関 しては，最も苛酷な条件で設計応力を定めれば不必要な 安全率をとることになりまた最すゆるい条件を用いれ ば危険である，設計応力は使用材料についての一定温度

(5) G. V.Smith: Properties of Melals at Elevated Temperature, MacGraw-Hill Co., (1950).
一定荷重のもとに扮ける標準クリープ試験のデータをる とにして定められるが，このデータが果して応力変動の もとで用いられる部材の設計応力の基準として正しい值 を与えるものであろうか，本稿に拉いてはかかる観点よ り，応力変動のもとに約るクリープ性質を明らかにす るとともに, これと標準クリープ試験結果との関連につ いて述べる。

一般に変動応力下のクリープはその応力の変動サイク ルの周期が比較的長い(数十秒以上)のものと 1 分間数百 サイクルないしは数千サイクル等の短周期のものに大別 されるが，本稿に括いては主として長周期の場合（周期 1 分〜数十時間) のものを取り扱 5 . 周期の比較的長い ものは一般に “変動応力下のクリープ”と呼ばれる. 本 稿に颃いて取り扱われるような変動応力下のクリープに おいてはとの周期が長く静クリープの範疇において取扱 い得る場合であり，それ以上短周期の場合は疲労，熱衝 撃などの䦕題も同時に加わつて来る。これらについては 本稿にふれない.

以上の区別は応力サイクルの周期の長短によつて，明 確に区別されるものではなく, 用いられる素材の種類, 使用条件によつてこれら区別の境界はかなり変化するも ので岕るが，実際の設計に際してこれらを如何に取り扱 うか，あるいはまた実際方法の上から区別している。

米圆に预いては1954年にASTM-ASME の合同企画 のもとにこの問題についてのシンポジゥムが開かれ, そ の論文が ASTM STP No.165(4) として出版されて拉り, それ以後に捈いても各国で種々論議されている.

ここでは主として変動応力下のクリープに関して筆者 らの現在まで行なつて来た研究結果を中心に諎外国の研 究成果を紹介しつつ比較検討し, この分野での研究の歴 史と将来について論じて見たい。

\section{(2) 長周期変動応力下のクリープ}

ここでは一定温度のもとで応力が比較的遅い周期（約 1 時間以上) で変動し，その挙動を解析するに際して， 応力減少時のひずみ邨びひずみ速度の遷移現象(ひず み回復)の効果があまり大きくない場合について述べる。 変動応力下のクリープ挙動を静クリープの挙動に対応 させて考えるとき, この両者に差があるとすれば

(a) 応力変動が組織の変化の進行に影響をもつ

(b) 応力増加時のひずみ执よびひずみ速度の過渡現象

(c) 応力減少時のひずみ执よびひずみ速度の過渡現象 (ひずみ回復)

などが考えられる。析出硬化型耐熱材料では高温に拈い て静的応力を受けるよりも変動応力を受ける場合の方が 析出などの組織の変化が促進されるということは, 高温 疲労扣よび動クリープに扣いてその可能性が認められて 
いるが(6), 現在問題にしているような長周期 (数時間以 上）の上らな場合はさ添ど顕著なものであると認められ た例はない，Substructure に対する影響は第二，第三の 点に関連するが，当然あり得ることは想像に難くない。

したがつて, 今問題にしているような長周期の変動応 力下のクリープに関しては上述の (b) 拉よび (c) の現象が 影響するが，このような長周期についてはとくに後述す るごとく(b) の現象が大きくその挙動に影響を与える. いま簡単のために第 1 図に示すごとく矩形波状の応力変 動を数時間以上の比較的長い応力周期で与えた場合, そ のクリープ曲線を図式的に示せば第 2 図のごとくなるこ

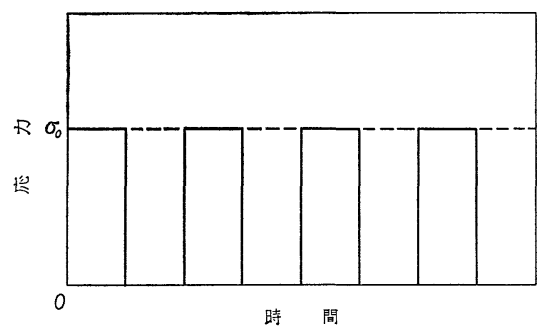

第 1 図 矩形波状変動応力 $\left(\sigma_{0} \leftrightarrow 0\right.$ 変動の場合 $)$

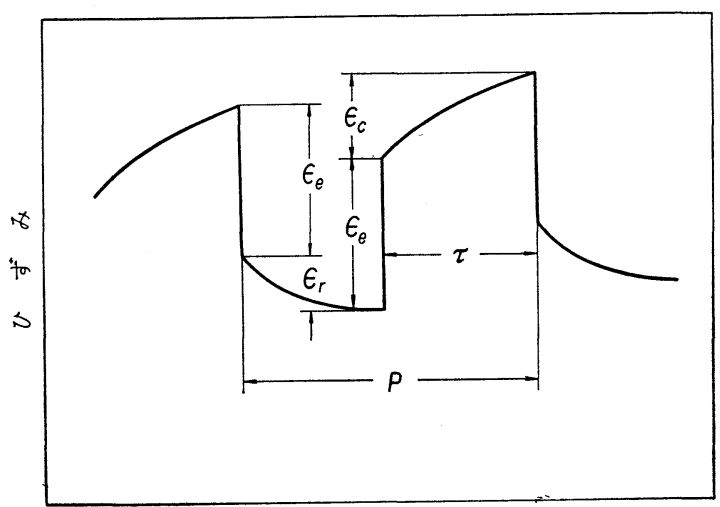

時 間

第 2 図矩形状変動応力下のクリープ曲線

とはよく知られている。すなわち，除荷と同時に弾性ひ ずみは回復し，応力休止(あるいは減少) 時間の経過 にともなつてわずかながらひずみが回復する。この時間 に依存するひずみの回復は通常“ひずみ回復 (strain recovery)”または “擬弾性回復 (anelastic recovery)” と して知られて招り，後節で述べるごとくそのひずみの減 少は時間に対して対数的であることが知られている(7). これらのひずみの減少は炭素鋼の場合添淁1 時間程度で 一定値に達する.ささらに応力休止期間終了後再負荷され た場合，まず負荷之同時弾性ひずみが生じ，それ続 いてクリープ変形が生じるが，この再負荷時に括けるク

(6) T.A.Hunter: ASTM STP, No.174 (1956),104. (7) J.W.L.Warren: Bristol Rep., No.54 (1965) .
リープ速度はその前の除荷直前のクリープ速度より増加 する現象が認められている。 これは応力休止期間（また は減少期間）中に金属材料が機械的性質を回復し，クリ ープ変形を生じやすい状態になつたためと考兄られてい る。このような効果は通常 “組織回復 (structure recovery または “thermal recovery)”として知られてい $る^{(7)}$.

上述の上万な現象は筆者らによる組織的には比較的安 定な炭素鋼に単純な階段状応力変動を与光たクリープ試 験結果に打いて認められた ${ }^{(8)}$ (10). 第3 図(10) は $0.14 \% \mathrm{C}$ 銅を $450^{\circ} \mathrm{C}$ に保つて行なつたクリープ試験結果をひずみ

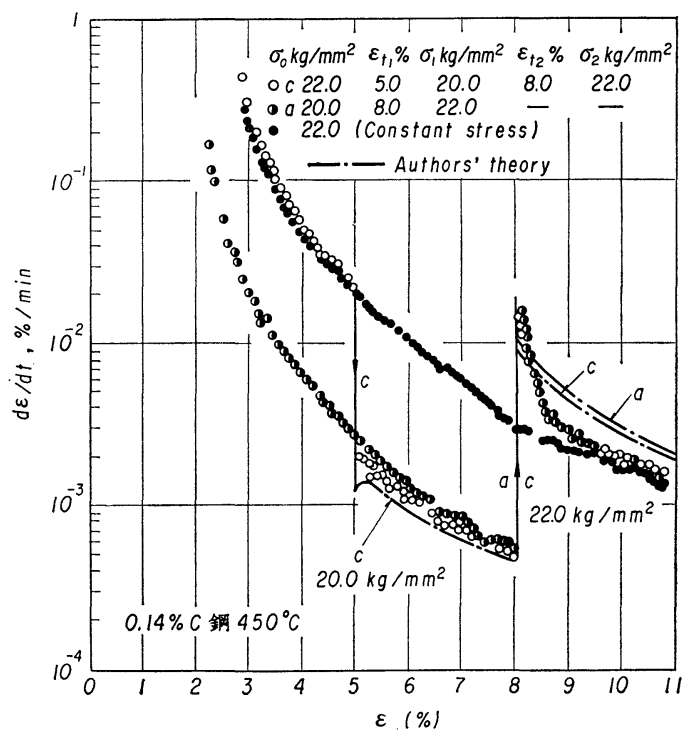

第 3 図 応力変動のもとに拈ける低炭素鋼 のクリープ

速度とひずみの関係で示したものであり, 図中黒丸は, $22.0 \mathrm{~kg} / \mathrm{mm}^{2}$ 亿応力を一定に保つて行なつた結果で他は 図の右肩に示す条件で, 最初 $\sigma_{0}$ なる応力で全ひずみ $\varepsilon_{t_{1}}$ までクリープさせた後, 階段的に応力を $\sigma_{1}$ に变光, そ の応力で $\varepsilon_{t_{2}}$ までクリープさせ, 再び応力を $\sigma_{0}$ に戻し たものである．いずれの場合にも応力を減少した時には (ただし無負荷の場合は当然クリープ変形は生じない.) その直後に下側応力に対応する丕速度よりはやや低いひ ずみ速度が現われ，ひずみの増加とともに急速に下側応 力に対応するひずみ速度になる。これに対して, 応力を 増加させた時は上側応力に対応するひずみ速度よりも著

(8) S.Taira: Creep in Structures, Colloqium held at Stanford University, California, (1962) , 96, Springer-Verlag.

（9）西原, 平,田中,大路：機械学会論文集，21 (1955), 791.

(10) 西原, 平, 田中,大路：機械学会論文集, 22 (1951), 832 . 
しく大きいひずみ速度が現われて，その後このひずみ速 度は次第に減少するがかなりひずみが增加するまでその 影響以認められる。すなわち，低炭素鋼の長周期変動応 カ下のクリープに扔いては前述のひずみ回復上りもむし ろ, 組織回復の方がその変形挙動に大きな影響を与兄, これが後に述べるごとく変動応力下のクリープに対して 固体状態方程式(11)*が厳密に適用し得ない主原因になつ ている.

以上は低炭素鋼の実験結果についてのもので岉り，低 炭素鋼についてはこの程度の周期での実験に新いてひず み回復の影響は顕著ではないが， $13 \mathrm{Cr}$ 鋼 $\left(950^{\circ} \mathrm{C}\right.$ で 30 分加熱後油焼入, $750^{\circ} \mathrm{C}$ で 60 分加熱)の $500^{\circ} \mathrm{C}$ に特け る応力変動下のクリープに物いてはこのひずみ回復が明 確に現わ礼，応力の減少によるひずみの回復が顕著であ る、第 4 図 ${ }^{(12)}$ は応力変動の周期を 24 時間とし，そのう

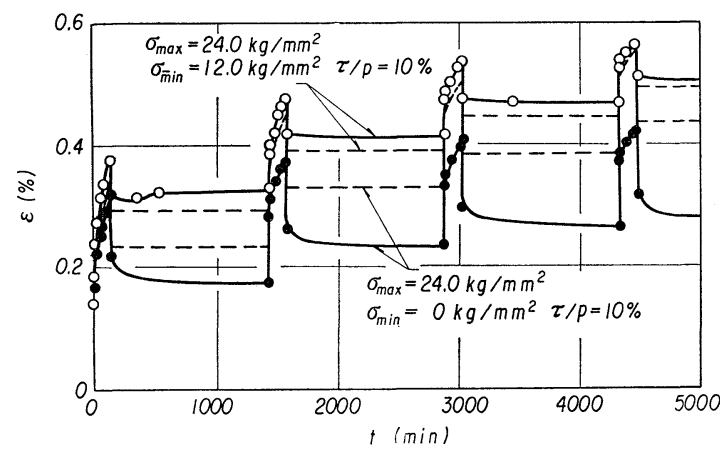

第 4 図 $13 \mathrm{Cr}$ 鋼の繰返し応力変動敊よび繰返 し応力休止のもとに特けるクリープ

ち 2.4 時間だけを $24 \mathrm{~kg} / \mathrm{mm}^{2}$ 飞保ち, 他の時間は $12 \mathrm{~kg} /$ $\mathrm{mm}^{2}$ に， あるいは応力を完全に除去した場合のクリ一 プ曲線の一部を拡大して示したものである. 図中点線 はそれぞれの場合に対し一定応カクリープ試矤結果より 固体状態力学方程式を用いて推定した曲線で岗る。この 場合に抒いてはひずみ回復の存在がクリープ変形挙動に 大きな影響を与兄るであろうことが推定される。

上に述べたことは応力変動の際に生ずる過渡現象であ

(11) P.Ludwick: Element der Technologischen Mechanik, Tulius Springer, Berlin, (1909),

* クリープの変形挙動を解析するに際して用いられ る基本的な考方方はいわゆる「固体状態方程式 (Mechanical Equation of State of Solid)」であり, これは「塑性変形過程にある材料の応力は, その 材料が過去に5けた応力や温度の履歴に関係な く，そのときのひずみ，ひずみ速度，応力执よび 温度によつて定まる」ということを意味するもの であり,

$$
f(\varepsilon, \dot{\varepsilon}, \sigma, T)=0
$$

なる方程式によつて表わされる。

(12) 平,田中, 大路：機械学会論文集, 25 (1959).
るが, 繰返し応力変動をうける場合には, これらの現象 が集積されてクリープ曲線上に表われる.

筠 5 図(13) $450^{\circ} \mathrm{C}$ に打ける繰返し応力休止のもとでのクリープで,

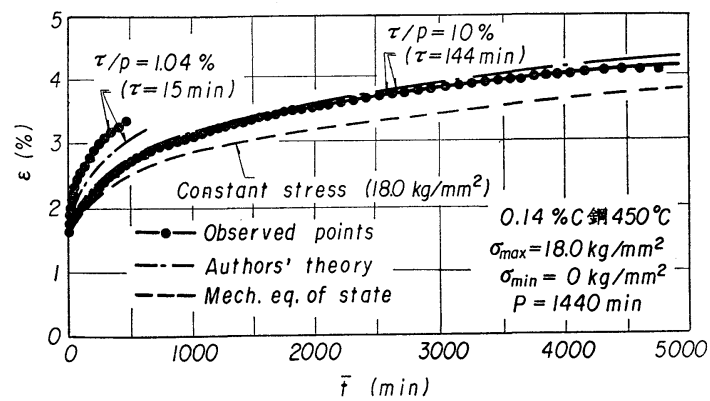

第 5 図 $0.14 \% \mathrm{C}$ 鋼の繰返し応力変動扔よび繰返 し応力休止のもとに括けるクリープ

図中 $\tau$ は応力を $18 \mathrm{~kg} / \mathrm{mm}^{2}$ に保つ時間, $p$ は応力変動の 周期である.横軸は試験時間のうち応力休止時間を除 きての総和 $\Sigma \tau$ をとつて示して山る。ささきに述べたごと く低炭素鋼は応力減少または除去時のひずみ回復が極め て小さく, 応力增加時の過渡的なひずみ増加（組織回復 の影響)が顕著なんめ, 同じ $\Sigma t$ に対しても応力繰返し 数の大なるもの汪ど（すなわらて/pの小なるすのほど）大 きいひずみを与えることがわかる，図中点線は固体状態 力学方程式による一定応力試験結果からの推定曲線で, このように実験結果から著しくはずれ，したがつてこの ような場合には推定值は危険側にあることになる。

同様のことは応力変動の周期 $p$ についてもいえる. この場合も同じ $\Sigma t$ に対して応力繰返し数の大なるもの

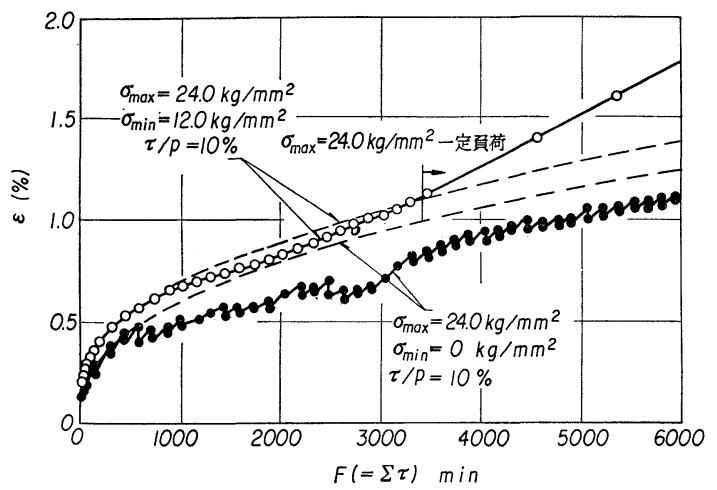

第 6 図 $13 \mathrm{Cr}$ 鋼の繰返し応力変動特よび応力休止 のもとに䋆けるクリープ曲線

ほど（すなわちpの小さいものほど）大きいひずみを与 えることがわかる、つぎに第 6 図(13) は第 4 図に示した $13 \mathrm{Cr}$ 鋼の繰返し応力休止の場合のクリーブ曲線を示し

(13) 平: 機械の研究, 11 (1959),1321. 
ているが，先述のごとくこの材料は応力上昇時の過渡的 なひずみの増加(組織回復) に対して, 休止時のひずみ回 復が大きいため, クリープ曲線は点線で示される固体状 態方程式による推定クリープ曲線より下に出る。したが つてこの場合は推定值は安全側である.

上は応力変動のうちで最も苛酷な条件である応力休止 の場合をる示したのであるが，一般構造物に括いてはむ しろ応力が上限と下限との間を変動する場合が多いと考 えられ，このときには応力変動に上るひずみの過渡現象 はその応力振巾の大きさに逆比例して小さくなる．第 6 図には $13 \mathrm{Cr}$ 鋼の $500^{\circ} \mathrm{C}$ に打壮限応力 $24.0 \mathrm{~kg} / \mathrm{mm}^{2}$, 下限応力 $12.0 \mathrm{~kg} / \mathrm{mm}^{2}$ のもとに和ける変動応力下のク リーブ曲線をも示しているが第 1 期叔よび第 2 期クリー プの段階では点線で示す推定曲線と非常によく合つてい る.しかしながら応力変動のもとでは第三期クリープが 一定応力クリープの場合に比しかなり早く現われること は注意しなければならない，この原因については光学顕 微鏡による組織観察では検知し得ないが，扣そらく substructure の変化に起因するものであろう．

\section{(3) 短周期変動応力下のクリープ}

2- (2) 節に扬いては低炭素鋼に扬いてはひずみ回復の 影響を汪とんど考慮に入れなくてもよい潘どの長周期の 変動応力下のクリープについて述べた。事実，低炭素鋼 に抢いては応力減少または除荷時のひずみ回復は小さ く, その值も注济 1 時間程度で一定值に飽和する。 しか しながら，周期が短かくなるにつれて，これらのひずみ 回復の蓄積効果は無視し得なくなり，このため低炭素鋼 の場合について述べるならば周期が 1 時間以下の変動応 力下のクリープはそれ以上の長周期の場合のクリープ変 形とはまた異なつた挙動を示すことになる(7).

一般に変動応力下のクリープに物いては第 2 図に示す ごとく，1 周期中に生ずるクリープひずみ量は負荷期間 中のクリープひずみ量を $\varepsilon_{c}$ と応力減少または除荷期間中 のひずみ回復 $\varepsilon_{r}$ の差として表わされ，この差が変動応力 下のクリープ挙動を支配するものであると考兄られる. いま,変動の周期が短かくなつた場合を考光るならば,当 然, 負荷期間中のクリープひずみ $\varepsilon_{c}$ は小さくなり，それ に比して $\varepsilon_{r}$ の減少量の変化はそれ注ど大きくないから, 1 サイクル中のクリープ変形量 $\varepsilon_{c}-\varepsilon_{r}$ は小さくなると考 えられる。

このように $\varepsilon_{\boldsymbol{r}}$ (ひずみ回復)の効果を無視し得ないよう な条件下のクリープに特いて, 応力変動の周期 $P$ の影 響を考えるに際し，い李，ここで，これらの現象を量的 に表わするのとして, 同一応力下に拈ける一定応力下の クリープ速度に対する変動応力下のクリープ速度の比を とり，これを $\Psi$ と定義する。すなおち，

$$
\Psi=\frac{\text { 変動応力下のクリープ速度 }}{\text { 一定応力下のクリープ速度 }}
$$

となる。

応力変動の周期が $\Psi$ に与学る影響を見るために， $\tau / p$ $=0.5$ の場合について応力 $\sigma$ をパラメーターにとり周期

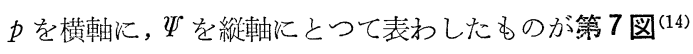

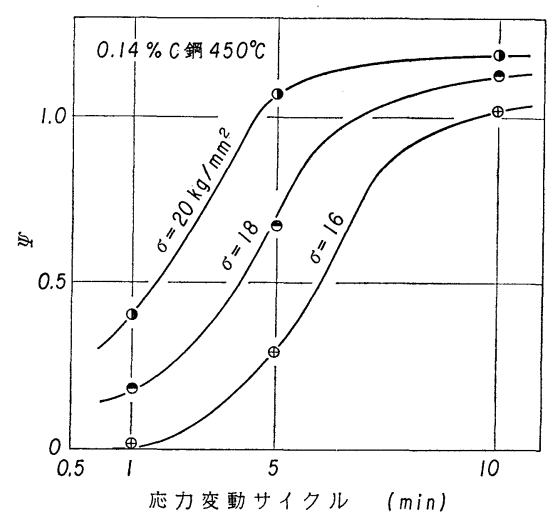

第 7 図 応力変動サイクルに対する $\Psi$ の変化

に示されている。すなわち, 周期が漂ぼ 1 分から 60 分の

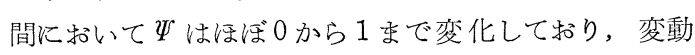
応力を加皃た場合の影響が周期により著しく異なりここ の過渡的な変化を与兄る周期の大ささは 1 分ないし 60 分前後であり, この領域は応力の增加に伴ない短周期側 へ移動することを示している.

このようにして, 低炭素鋼汇物いては変動応力の周期 が約 1 時間以下の領域に水いて $\Psi$ の值は 1 より小さく なり，応力休止または減少期間に特けるひずみ回復の効 果が無視し得なくなる.ここで $\Psi=1$ ということは一定 応力から変動応力に切り換えても両者のひずみ速度には 変化がないことを意味して拈り, 変動応力による影響が 現われない。したがつて，この場合はひずみ硬化説が成 立していることになる. $\Psi<1$ といらことは変動応力下 のクリープ速度が一定応力下のクリープ速度よりも小さ い場合で脑り，西る時間に対するクリープひずみ量はひ ずみ硬化説から推定されるクリープひずみ量よりも小さ くなり, したがつて変動応力の場合の方が時間強度が大 きいことを意味し，ひずみ硬化説は成立しないことにな る.さらに, $\Psi>1$ とい5ことは変動応力下のクリープ 速度が一定応力下のクリープ速度よりる大きい場合で, ある時間に対するクリープひずみ量はひずみ硬化説から 推定されるクリープひずみ量より大きくなり，やはりひ ずみ硬化説は成立しない，これは周期の大きい場合古る いは応力の高い場合に観察される現象である.

さらに, 長周期の場合と同様に短周期矩形波状の変動

(14) 平, 小寺沢, 平: 未発表. 
応力下のクリープ変形のもとでは 1 周期中の負荷時間 $\tau$ と応力変動の周期 $p$ との比, すなわち $\tau / p$ の值がクリ 一プ変形の挙動に対して与学効果についても観察する 必要がある、第 8 図(15) は筆者らが $0.16 \%$ 鋼について，

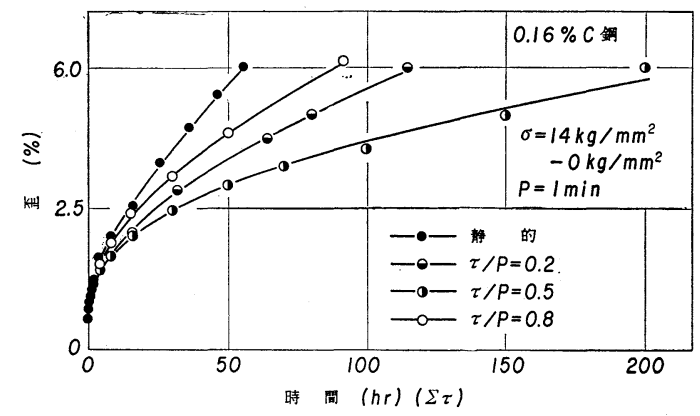

第 8 図 $0.16 \%$ C 鋼に特ける $\tau / p$ による リープ曲線の相違

$450^{\circ} \mathrm{C}$ の一定温度のもとで $\tau / p$ の值をそれぞれ $0.2,0.5$, 0.8 に変化させてクリープ試験を行なつた場合の一例で ある. 図中・印は $14 \mathrm{~kg} / \mathrm{mm}^{2}$ の一定応力のもとで行な つた静クリープ試験の結果であり, ○印は $\tau / p=0.2$, は $\tau / p=0.5, \bigcirc は \tau / p=0.8$ の場合を示している。ただ し，この場合横軸はすべて負荷時間の 総和 $\Sigma \tau$ で示され ている. 同図から明らかなごとく，長周期の場合とは異 なりそのひずみ速度はかならずしも $\tau / p$ の值が小さいほ ど大きいとい5 現象は現われず， $\tau / p$ の值が 0.8 のすの がそのクリープ速度が一番大きく, 続いて $\tau / p=0.2$ の 場合となり, $\tau / p=0.5$ の場合のクリープ速度は一番小 さくなつている、しかしながら，これらのすべては前述 のごとくひずみ回復の影響を大きく受けて，・印で示さ れる静クリープの場合よりそのひずみ速度は小さくなつ ている.

以上述べたごとく, 変動応力下のクリープに関しても その周期が大きい昜合と小さい場合とでは, クリープ変 形挙動にかなりの差異が存在し, 今後, この方面での資 料の蓄積之理論の発展が期待される.

\section{(4) 変動応カ下のクリープに対す る諸理 論}

\section{(i) クリープ破断に関する理論}

Robinson(16) は温度执よび応力の変化する場合の材料 のクリープ破断寿命を標準クリープ破断試験結果から推 定するための考え方を基準として，「ある寿命の消耗率 はそのとさの応力执よび温度のみによつて定まり，他の

(15) 平, 中西, 高橋：1966 年 10 月本会尼崎大会に講 演.

(16) E.L.Robinson: ASME Trans., 60 (1938) , 253; 74 (1952) , 777 .
状態に打ける消耗率とは無関係である」という基本的な 仮定を設け，この仮定のもとに種々の場合を論じた。 こ の考え方によれば温度, 応力の変動する場合のクリープ 破断寿命は標準試験の結果からつぎのようにして推定す ることが出来る.

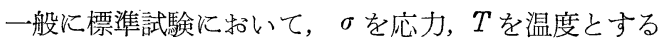
と破断寿命 $t_{r}$ は次式によつて表わされる.

$$
t_{r}=C \sigma^{-P} e^{q T}
$$

ここに $C, P$ および $q$ は温度に無関係な定数である。一 定温度試験では $\log t_{r}$ と $\log \sigma$ が比例することを意味し ている，いま応力 $\sigma_{0}$, 温度 $T_{0}$ なる標準試験を行なうと $t r_{0}$ なる破断時間を与えるものとする。ところが予想せ られる全寿命の中, 実際は $f_{i}$ の部分が応力 $\sigma_{i}$, 温度 $T_{i}$ になるものとすると，実際の寿命は $t^{\prime}{ }_{\boldsymbol{r}}$ であるとする。 すると

$$
\frac{t_{r 0}}{t^{\prime}{ }_{r}}=\left(1-\Sigma f_{i}\right)+\Sigma\left[f_{i}\left(\frac{\sigma_{i}}{\sigma_{0}}\right)^{P} e q\left(T_{i}-T_{0}\right)\right]
$$

により標準破断試験の場合より寿命の短縮または増加の 割合が与えられる。

Robinson 法は計算が比較的簡単なため, 変動応力,変動 温度のもとでの寿命を標準クリープ破断試験結果から推 定する一つの基準となつて扣り，多くの研究者によつて その推定値の吟味が行なわれているが(4)，この理論の適 用範囲には温度限界が存在し,この温度以下では Robinson 法による推定值は実験值とよく一致するが，その 限界温度をこえると実際寿命は推定值よりも短かくなる ことを示している。また，Robinson 法によれば寿命の消 耗の過程に応力や温度の履歴の影響を無視し, 殊に温度 や応力の急変の際に生ずる遷移現象も全然考慮していな い. これらの効果がクリープ破断寿命に与觉る影響につ いて考察を加えることはかなり困難な間題であるが，今 後の課題となるであろら.

\section{(ii) クリープ変形に関する理論}

温度, 応力が変動する場合のクリープ破断寿命を推定 する基本的な考方方でる Robinson 法に対して，標準 クリープ試験結果から温度, 応力が变動する場合のクリ ープひずみまたはひずみ速度を推定する基本的な考光方 は，いわゆる「固体状態力学方程式」である。すなわち

$$
f(\varepsilon, \dot{\varepsilon}, \sigma, T)=0
$$

この式はクリープ変形中の諸量の関係のみを示すもので はなく, 広く一般の塑性変形過程全般に扣ける諸量の関 係についての基本的過程である.

固体状態方程式が実際の材料の変形過程に括いて一般 に成立するものであるか否かについては多くの論議があ り (17) (19)，ことにクリープのごとき組織敏感な変形過 程に扣いては, 温度履歴, 応力履歷吕組織変化に影響を 
与えることが考光られ, クリープの場合, 物理学的な観 点に立脚すれば原則的には固体状態方程式は成立しない と考光るべきである、しかしながら，乙れは簡単な仮定 にもとついいて抮り，したがつてこれによるとクリープに 関係する工学上の間題が容易に取り扱えるという利点も 票り，現在この考方を基礎として変動応力下のクリー プに関する諸問題を解明するための理論が数多く提出さ れて扬り,さらに進んで固体状態方程式の中に温度, 応 力などの履歴の影響を導入しょうとする考方方わいくつ か提出されている.

さて, 上述のごとく固体状態方程式に泾いては, 塑性 変形過程にある材料の応力は (2.4) 式に上つて表わされ るのに対し，変動応力下のクリープに特いてはその応力 変動の履歴が金属材料の組織に影響を与兄, その変形挙 動は2-(2) 拉よび2- (3) 節で述べたごとく固体状態方程 式から推定される值より大きくはずれて来る. そこでこ れらの固体状態方程式からのずれを修正するために, 固 体状態方程式の中に組織変化の影響を考慮に入れた変数 の導入が試みられた。この方面での理論的な解析には Kennedy ${ }^{(20)(21)}$, Dorn ${ }^{(18)}$ (22), 平, 大路(8) (10) (13), Rabotonov (23), Lubahn(24), Conrad(25)などがある.

これらの理論の多くは前述の固体状態方程式が

$$
f(\varepsilon, \dot{\varepsilon}, \sigma, T)=0
$$

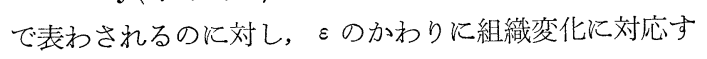
る変数 $q$ を導入しようとするものである。すなわち

$$
f=\left(\dot{\varepsilon}, \sigma, T, q_{1}, q_{2} \cdots \cdots q_{n}\right)=0(7)
$$

で表わされる.ここで変数 $q_{i}$ は次のごとく定義される.

$$
d q_{i}=a_{i} d \varepsilon_{c}+b_{i} d \sigma+c_{i} d T+d_{i} d t^{(7)}
$$

ここで, $a_{i}, b_{i}, c_{i}, d_{i}$ はそれぞれクリープ企 $\varepsilon_{c}$, 応力

$\sigma$, 温度 $T$, 時間 $t$ の関数である.

さて, これら $q$ の項汶して上述の多くの研究者達に よつて種々の考光が提案されているわけであるが,

(17) J.H.Hollomon and J.D.Lubahn: General Electric Review, 185, Feb., April (1947)

(18) T.E.Tietz, R.A.Anderson and J.E.Dorn: AIME Trans., 185 (1949) , 921.

(19) E. G. Ripling and G.Sachs: AIME Trans., 185 (1949) ,78.

(20) A. J. Kennedy : Proc. Roy. Soc., A 213 (1952), 492.

(21) A.J.Kennedy : Proc. Phys. Soc., 68-B(1955), 257.

(22) O.D.Sherby, T.A.Trozera and J.E.Dorn: Proc. ASTM, 156 (1956) , 789.

(23) Y. N. Rabotnov : Joint Int. Conf. on Creep, 2 (1963), 117.

(24) J.D.Lubahn and R.P.Felgar: Plasticity and Creep of Metals, John Wiley, (1961).

(25) H.Conrad: Experimental Evaluation of Creep and Stress Rupture, Ch.9.
Kennedy (20)(21) は純形式論的な考方方で，忘力休止期間 の材料の回復を取り入れようとするものであり, この方 面に括汗る研究の先駆的な役割をは先したが, 理論的根 拠にとぼしい点もあり，現在ではあまり有效な考方方と しては認められていない。

$\operatorname{Dorn}{ }^{(18)(22)}$ の理論は $(2 \cdot 6)$ 式に扮ける变数 $q_{1}$ を

$$
q_{1}=f\left\{t e^{-Q c / R T}\right\}=f\left\{Q_{c}\right\}=\varepsilon
$$

$t$ : 時間； $Q_{c}$ ：応力に依存するクリープに対する 1

モル当りの活性化エネルギー； $R$ : ガス定数; $T$ : 温

度; $Q_{c}$ : Dorn parameter

と招くことを基礎としており，この Dorn parameter $Q_{c}$ はクリープ変形中に生ずる substructure の状態によつ て一義的に決るものであるとしている。すおわち，彼の 考え方によれば応力の履歴の影響を substructure の変化 として表わし, 変動応力下のクリープの問題を取り扱う ことを試みているが，着想としては扔もしろいが末だ成 功しているとはいい難い.

筆者 ${ }^{(8) \sim(10)(12)(13)} ら$ の考光は履歷（応力履歴と温度履 歴を含めて) の影響を生ぜしめる原因は主として時間的 に進行する substructure の回復であると考光, 加工硬化 と structure recovery (strain recovery と異なることに 注意）とを考它併せて塑性変形過程を論じようとするも のである、すなわち， $(2 \cdot 5)$ 式に拈ける $q_{1}$ をなる変数 に扮いた，ここで $\bar{\sigma}$ は材料の内部降状応力を表わするの である・すなわち $(2 \cdot 4)$ 式示される固体状態方程式に打 いては，要るときの材料の変形抵抗はとのときのひずみ の大いさに依存するのに対し，筆者らの理論に特いては 可すなわち内部降状応力に依存する向のと考光る。可は その段階に和ける塑性変形に対する抵抗を示するので, これには過去に抬ける応力や温度の履歴が影響し, これ らの関数として与えられている. かくして，応力のみな らず温度履歷をも考虑してクリープ(一般塑性変形をも) 論ずることができる.

上述の筆者らの考方方に対して Rabotnov ${ }^{(23)}$ とLubahrn (24) は structure recovery の特性はひずみ硬化の減小速度 が塑性ひずみに比例し，時間と温度の両者に依存すると いら考光を基礎にして，(2.5) 式に和ける $q_{1}$ に対して $\epsilon^{\prime} P$ なる相当塑性ひずみを採用した，彼らはこの相当塑 性ひずみの增分 $\delta \epsilon^{\prime} P$ に対して次式を採用した。

$$
\delta \epsilon_{P}^{\prime}=\delta \epsilon_{P}+\frac{\partial \epsilon_{P}^{\prime}}{\partial t} \delta t
$$

さらに, Lubahn ${ }^{(24)}$ はこの相当塑性ひずみをつぎのよう に提案している.

$$
\delta \epsilon_{P}^{\prime}=\delta \epsilon_{P}-H \epsilon^{\prime} \delta t
$$

ここで，Hはstructure recovery rateである。また， Conrad ${ }^{(25)}$ は筆者らと同様の相当応力なる概念を導入し， 
$q_{1}=\sigma^{*}$ なる変数を採用し， $\sigma^{*}$ に関てし次式を提出した．

$$
\sigma^{*}=\int_{0}^{\epsilon_{P}} h\left(T, \dot{\epsilon}_{P}\right) d \epsilon_{P}
$$

筆者らの理論によればこの内部降状応力 $\sigma^{*}$ の増分 $\delta \sigma^{*}$ は次によつて表わされる。

$$
\delta \sigma^{*}=\frac{\partial \sigma^{*}}{\partial \epsilon_{P}} \delta \epsilon_{P}+\frac{\partial \sigma^{*}}{\partial t} \delta t
$$

したがつて, $(2 \cdot 9)$ 式の函数 $h$ は

$$
h \equiv \frac{d \sigma^{*}}{d \epsilon_{P}}=\frac{\partial \sigma^{*}}{\partial \epsilon_{P}}+\frac{\partial \sigma^{*}}{\partial t} \frac{1}{\dot{\epsilon}_{P}}
$$

となり, 内部降状応力は $\sigma^{*}$ は

$$
\sigma^{*}=\int_{0}^{\epsilon_{P}} h\left(\sigma^{*} \cdot \epsilon_{P}\right) d \epsilon_{P}
$$

として表わされることになる.

さて，以上述べたいくつかの理論は変動応力下のクリ ープに対してその挙動を主として応力休止または減少時 に持ける structure recovery の効果のみによつて解釈し ようとするものであり，たと党ば低炭素鋼を例にとつて 見るならば, 応力変動の周期が数時間程度以上の長周期 のものや, strain recovery の小さいものについてはかな り正確な推定值をもたらすことが可能であるが，短周期 のものについてはこの strain recovery の効果を見のが すことは出来ない，一般にこのような応力の変化によつ てもたらされる過渡的現象は第 2 図に $\varepsilon_{r}$ によつて示さ れるような形の strain recovery のみではなく，箭9図 および第 10 図に示すごとき現象など,材料の種類, 負荷

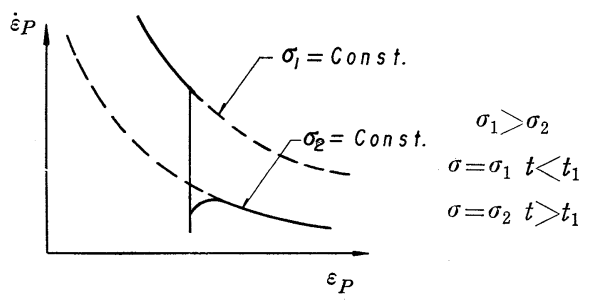

第 9 図 応力減少時の過渡現象

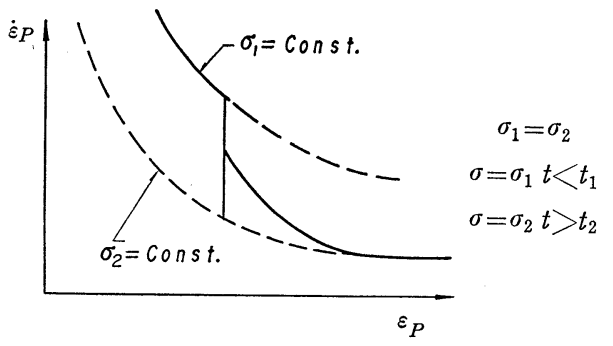

第 10 図 応力減少時の過渡現象

条件,温度などにより種々の場合が報告されて扔り,これ らの現象に対しても，Manson(26), Namestnikov(27), Rabotnov (23)，筆者ら (28)によつてその理論的解析が
進められているが，これらの理論的解析の基礎的な考 方方は (2.5) 式に示される $q$ の項に対してこの現象をい かに導入するかという方向にある. したがつて, 前述の structure recovery に関しては $q_{1}$ の項として考慮した のに対して，ここで考光る現象は $q_{2}$ の項として $(2 \cdot 5)$ 式に導入される。

さて, Manson(26) はこの応力減少の際に生ずる過渡現 象はすべり带の形成とその成長に限界が出ることに起因 するとして，この問題に見解を示している。これに対し て Namestnikov(27) と Rabotnov(23) (27) の考完は転位の障 害からの離脱に関係があるとして，相当応力なる概念を 導入し， $q_{2} \equiv \sigma^{\prime}$ とし， $\sigma^{\prime}$ を次式で表わした。

$$
\sigma^{\prime}=\sigma+a \int \varepsilon_{c} d \sigma
$$

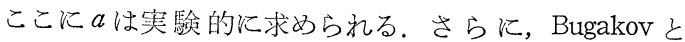
Vakulenko(29) は $q_{2} \equiv \varepsilon^{\prime} P$ なる相当望性ひずみの考えを導 入し, 次式を提昌している.

$$
\sigma \epsilon_{P}^{\prime}=\int_{0}^{\epsilon_{P}} \sigma d \epsilon_{P}
$$

筆者らは応力変動下のクリープに特けるこのような現象 は thermal recovery とひずみ硬化の過程が密接に関係 しているものと考えている。すなわち，高応力のもとで 転位の pile-upによつて硬化している材料はそれに続く 応力の減少によつて, これらの pile-up している転位が climb up の過程を経て active な slip plane から上昇する ことにより，pile-up している転位の “spring back”によ つて時間に依存するひずみ回復が生ずるものと考兄られ る(28). そして, これらの過渡現象を解明するためには flow stress $\delta \sigma^{*}$ を急激に減少させる実験 結 果を $(2 \cdot 11)$ 式に適用することによつて推定しうることを示した(28). 筆者らが観察したごとき現象について Dorn も観察を行 なつて特り (18)，筆者らの結果とかなりよい一致を示し ている.

以上, 変動応力下のクリープ挙動を主導的に支配する 二つの要因である structure recovery と strain recovery の効果をいか固体状態方程式に導入し，金属材料の組 織変化まで考慮に入れた金属材料のクリープに関する統 一的な方程式の確立に対していかなる努力がはらわれて

(26) S.S.Manson : Creep Under Nonsteady Temperature and Stresses Ch. 14. Mechanical Behaviour of Materials at Elevated Temperatures, Ed. J.E. Dorn, McGraw-Hill, (1961) .

(27) V.S. Namestnikov and Y.N. Rabotnov: Regarding the Hypothesis about the Equation of State under Conditions of Creep, Zh.P.M.T.F., (1961) (3) $101 \sim 102$

(28) S. Taira, K. Tanaka and K. Ohji : Bulletin of J.S.M.E., 4 (1961) .

(29) I.I.Bugakov and A.A.Vakulenko: I.A.NSSR. M.M.No.6 (1963) . 
いるかについて簡単に述べてきた。もちろん，金属材料 の組織变化飞依存する現象としては, これ以外にる strain aging, aging, overaging, secondary hardening, precipitation, transformation などその用いられる材料 および使用条件によつて考慮する必要があることは当然 であり，そのためには $(2 \cdot 6)$ 式の $q_{3}, q_{4} \cdots$ の各項に関して

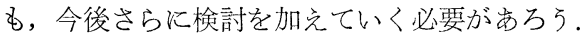

\section{3. $\mathrm{X}$ 線による変動応力下の クリープに関する研究}

第 2 節で述べてきたごとく，変動応力の下クリープに 関する研究は，まずその現象の把握からはじまり，それ らの現象をひずみ, ひず文速度, 温度, 応力など の巨視的汇観察しらる状態量を用いて，固体状態 方程式によつて解析しょうとする試及からはじま つた。しかしながら，この上うな状態量のみでは 十分にこれらの現象を把握することが困難で峁る ことが明らかとなり，この固体状態方程式偟金属 の組織変化依存する変数を導入し，上り完全な 方程式の完成を目ざして種々の努力がなされてい る。しかしながら，これらの努力の多くは依然と して測定された状態量加ら逆洎織变化に上る効 果を推定している場合が多く，その物理的根拠に そしい感はまぬがれない。

一方，金属物理学の分野に扮いては非常に単純化され た条件のもとでのクリープ現象に関して種々の物理的実 験が行なわれて招り，これらの研究によつて得られた知 識はわれわれに大きな参考資料を提供してくれるが，か ならずしも一対一飞対応する上うな場合が多いとはかぎ らず，両者の間汕はなはだ大きなギャップがあること を認めないわ秋はいかない。

このような観点に立脚して,筆者らは非常に structure sensitive な観察手段であるX線回折技術を用いて変動応 カ下のクリープ挙動を観察し, これらの観察結果をもと にして，真に物理的根拠のある parameterを用いてこ の変動応力下のクリープを理論的に解析することを試み ている.このような観点に立脚した研究はまだその例は 少なく, 筆者ら (30) (32) の研究も開始以来年月も浅く今 後の発展に期待するところ大である.

さて，第 12 図(31) 示されるクリープ曲線は $0.16 \% \mathrm{C}$ 鋼を $450^{\circ} \mathrm{C}$ の温度のもとで，周期 $p=24$ 時間, $\tau / p=0.5$ の第 11 図(31) に示すごとき矩形波状の変動応力のもとで

(30) 平, 中西, 川辺，：材料，第 14 巻，第 147 号 (1965) 1007.

(31) 平, 中西, 高橋: 材料, 印刷中,

(32) S. Taira, E. Nakanishi and T. Takahashi : Proc. of the 10th Jap. Cong. on Test. Mat.
クリープ変形させた場合のものである。同図に扔いて○ 印は変動応力下のクリープ曲線, ・印は $14 \mathrm{~kg} / \mathrm{mm}^{2}$ の

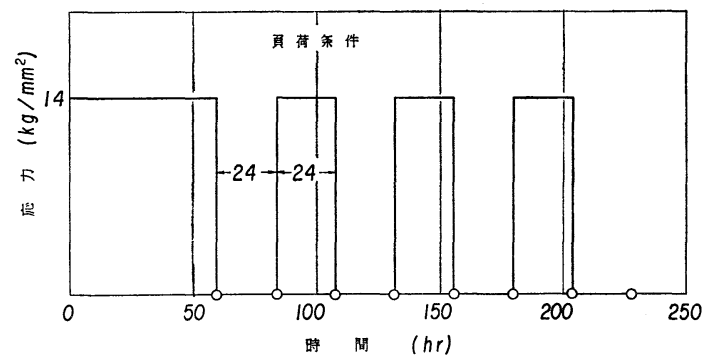

第 11 図負荷条件

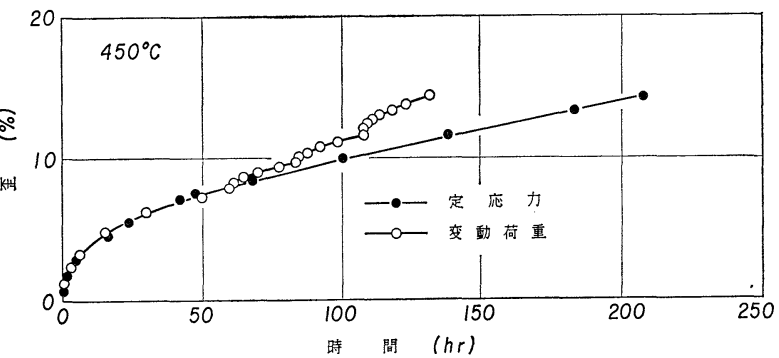

第 12 図 $0.16 \% \mathrm{C}$ 鋼に括ける一定荷重下括よび 変動荷重下のクリープ曲線

一定応力試験結果である。ただしこの場合も横軸のクリ ープ時間は負荷時間の総和によつて示されている．同図 からも明らかなごとく，このような長周期に扔いては応 力休止期間中の structure recovery の影響が大きく, 変 動応力下のクリープ速度は一定応力試験の場合のクリー プ速度よりも大きくなつている。

このような応力休止期間中の structure recovery の影 響が金属組織のいかなる変化に起因し，これらの変化が 巨視的なクリープ挙動にどのようにして影響を与えるか を観察するために応力変動の各半サイクルの間に生ずる 金属材料の結晶微細構造の変化を主として細束 X線技術 を用いて追求した。それれらの結果が第 13 図，第 14 図第 15 図, 第 16 図 ${ }^{(31)}$ 亿示されている。第 13 図は第 11 図に 示寸応力変動の各半サイクル終了後の試料上り得られ る, $\mathrm{CoK}_{\alpha}$ 特性 X 線の回折強度曲線の 半価巾值の変化を 示したものであり,実線で示した期間は応力負荷期間, 破 線の部分は応力の休止期間を表わしている．同図によつ て示されるごとく，負荷期間中にはひずみ硬化の進展に ともなつて, 半価巾值が増大し, 応力の休止期間炕と のひずみ硬化の回復にともなつて半価巾值が減少し，応 カのくり返しに対して，ジグザグ状の変化を示してい る.これらの変化からはひず硬化の進展とその回復が 結晶構造の乱れとその回復に起因していることは直感的 に把握でさるが，さらに微細な機構について観察するこ 
とは困難である。

そこで筆者らはこの方面の研究に細束 X線技術を採用

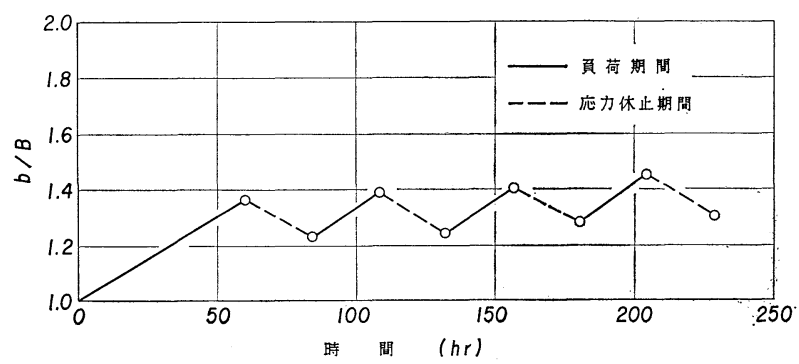

第 13 図 変動応力下のクリープに拈ける半価巾值の変化

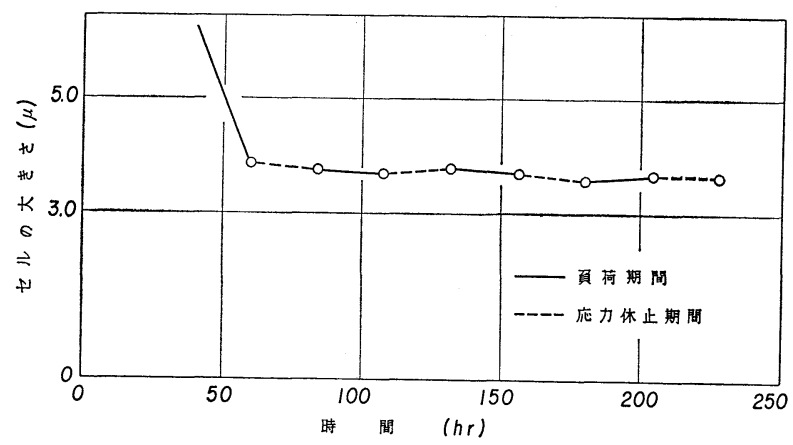

第 14 図 変動応力下のクリープに拈ける cell size の変化

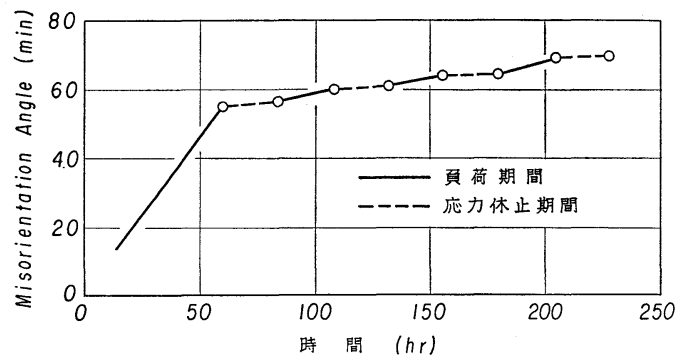

第 15 図 変動応力下のクリープに护ける misorientation angle $の$ 変化

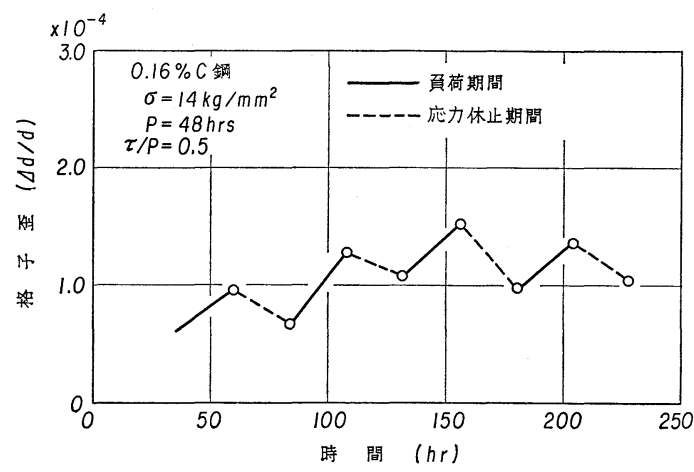

第 16 図 変動応力下のクリープに特ける格 子柾の変化
することにより, より微細な 結晶構造の変化を観察し た. 第 14 図(31) は半価巾の場合と同様, 細束 $\mathrm{X}$ 線回折パ ターンをHirsch(33) の方法汇よつて解析すること によつて得られる subgrain size の応力変動の各 半サイクル間に生じる変化を表わしたものであ り，応力変動に対して subgrain size はあまり 変化せず, 変動応力下のクリーブに対しては subgrain size があまり大きな影響を与えないであ ろらことが考えられる.ささらに, 回折 Debye 環上 の回折斑点の接線方向の広がりから, 結晶の total misorientationの变化を求めたものが第 15 図 ${ }^{(31)}$ である。同図に扔いて明らかなごとく, total misorientation angle は負荷期間中に增加するが，応 力の休止期間中にはあまり变化しないで, 応力の 繰返しに対しては階段状に変化して行く。いま, total misorientation angleは結晶に存在する過剩転 位密度の存在に対応すると考它られるから, 同図 により負荷期間中に括いてはひずみ硬化により転 位密度が増加するが, 応力休止期間中の structure recoveryによつてはこの温度条件のもとではあま り変化しないと考兄られる。さに, 細束X線に よる回折パターンに捈いては，回折斑点が拡散す ることによつて形成するアーク中に細かく分離し た subgrainの存在を示す斑点が現われる。これら の斑点の半径方向への拡がりを測定することによつて, subgrain 内の結晶格子に存在する弾性ひずみに分布範囲 に関する知識が得られる・いま,この值を $\Delta d / d$ なる形で 表わし，これを lattice strain よよぶことにする，第 16 図(31) はこのようにして求められた lattice strain $\Delta d / d$ の 応力の繰返しに対する変化を示したものでまり, 同図よ り明らかなごとく, subgrain 内部の格子ひずみ $\Delta d / d$ は応 力の繰返しに対してジグザグ状の変化を示し, 前述の半 価巾の変化とよい対応を示している. この lattice strain $\Delta d / d$ の值は subgrain 内部に存在する転位の密度と密接 な関係を有することが涩められて搞り ${ }^{(33)}$ ，これらの考 えに立脚するならば, subgrain 内部の転位密度は応力の くり返しに対して，負荷期間中に増加するが，応力の休 止期間中には減少することを示している，以上の結果を 総括して変動応力下 (長周期の場合)のクリープに括ける 変形機構をとの細束 X 線回折バターンと対比させて図式 的に表わしたものが第 17 図 ${ }^{(31)}$ である，同図 (a) は第 1 回目の負荷の半サイクルが終了した直後の試料から 得られる回折パターンとそれに対応する金属の微細構 造である，同図に掠いては転位は subgrain wall 以外の

(33) P. B. Hirsh and J. N. Keller : Acta Cryst., 5 (1952), 162 . 
内部にもかたり存在して特り,したがつて回折斑点は拡 散して連続的になつている. これにつづく応力休止の半

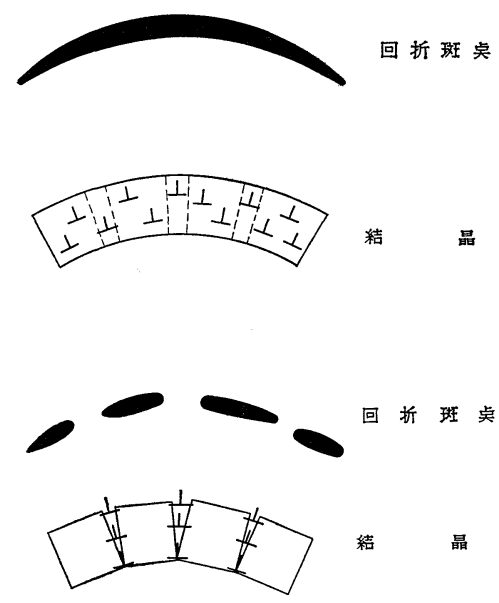

(a)

第 17 図 変動応力下のクリープ変形機構

サイクル終了後には (b) 図結晶の misorientation そのも のはあまり変化しないが，その転位配列はかなり異なつ たものとなり, subgrain 内の転位密度は小さくなり, subgrain wall への転位の集積が明確となる。このよう な状態で再負荷される場合, subgrain 内の転位の増殖, 移動は前回の負荷の半サイクル終了直後の状態よりよ り容易になり大きなひずみ速度をもたらすであろう。こ のようなくり返しによつて長周期の変動応力下のクリー プに执いては, 応力の休止または減少時の structure recovery が影響して, 一定応力下のクリープ試験の場合
よりも大きいひずみ速度を与觉ることになる．このよう な考えから筆者らがさきに提案した内部降伏応力 $\bar{\sigma} は$ subgrain 内の転位密度, 増殖, 移動などに密接な関係の あるものであろろことが推察される.

以上述ベたごとく，変動応力下のクリープに抒いては substructure に対する考察を抜きにして論ずることがで きないのであるが，筆者らはさらに，このX線回折技術 によつて得られる structure sensitive な諸量を定量化し 固体状態力程式に導入すると同時に，それらの変化に対 して金属物理学的な研究分野で得られた種々の基礎理論 および実証によつて裏付けられたとき, 真の変動応力下 のクリープに対する方程式が提出されるであろうと考え ている．筆者らはこのような方向づけのもとに変動応力 下のクリープのみならず，金属の塑性挙動全般にわたつ て研究を行なつている.

\section{4. 結言}

以上述べてきたごとく変動応力下のクリープに関する 研究は初期の力学的挙動の観察から固体状態方程式によ る解析およびそれへの structure factor の導入による修 正を経て，現在それらの structure factor の実証段階に あり，かつてこの分野の研究に沏いて現在ほど金属物理 学と材料力学の両研究分野の境界をうずめるべき努力の 必要性を痛感させられる時期はなかつた。 その意味で, 筆者が本誌上にこの小文を揭載する機会を与兄ていただ いたことを感謝する次第である.

\section{紇}

三宅八幡の赤い鳥居をくぐるとほどなく左方田畑に 囲まれたいかにも閑静な邸宅が目につく，洛北の景勝 比颚の峯を配した庭園には池あり茶室あり, 京の四季 を居ながらに賞でることのできる八瀬の近郊に沢村先 生が移られたのは昭和 29 年 11 月であつた. 先生は元 来転宅が扔好きで, 私の知る限りでも鞍馬口, 冏崎, 鷹が峯それに現在の三宅八幡としばしば転居され, 気 分を新たにしてご勉学に励まれたようである。令夫人 の扣話しによると現在の拈宅はとくに先生の叔気に召 しているとのことで (もつとも令夫人は日常の買物が 不便だとあまり賛成しておられないが), 都会の喧噪
を避け，高野川のせせらぎはあくまで清く，気はおの ずから静まり, 風光明媚, 京の田舎とはまことにこの ような土地をいらのであるう。

先生は昭和 33 年 4 月に京都大学を定年御退官にな られたが，御静養のいとまもなく鉄鋼業界の要望に応 えられて鉄鋼短期大学の創設に着手された，時市たか も全国的に学部・学科の新設あるいは講座の増設ブー ムで教職員が払底していた時代であるが，陣容を整え るには大変な御苦労をなされた，とにかく当時は名誉 教授室に連日のようにご出勤? になり, 構想を捏り計 画しかつ実行されたのである. 